www.nature.com/jhg

\title{
'Early Neolithic' graves of the Carpathian Basin are in fact 6000 years younger-Appeal for real interdisciplinarity between archaeology and ancient DNA research
}

Journal of Human Genetics (2012) 57, 467-469; doi:10.1038/jhg.2012.36; published online 7 June 2012

In the Journal of Human Genetics, volume 56, issue 11(15 November 2011), an article about the Early Neolithic genetic composition of the Carpathian Basin was published. The article claims that some of the individuals examined in the course of this study belong to the mitochondrial haplogroup (hg) N9a, which is common in East Asian and virtually absent in European/West Eurasian populations. The inferred discontinuity between the first farmers in Hungary and the modern population is specifically based on the appearance of this haplogroup, hitherto absent in the European Neolithic dataset. Here we wish to point out a number of serious mistakes in the dating of the skeletons investigated as well as the phylogenetic classification of the generated mitochondrial HVS-I sequences, which have a significant influence on the interpretation of the genetic data.

A number of well-known Neolithic sites are involved in this study, such as Szarvas 23, Szakmár-Kisülés and Csongrád-Bokros. However, all these sites were occupied in several archaeological periods, prehistoric and early historic. With a multi-period site, the skeletons have to be handled with special care to the archaeological contexts. If there is any doubt about the date, it is essential to establish the absolute date of each skeleton investigated. In the article in question, the following examples are wrongly dated:

(I) Szarvas 23, with two graves claimed to belong to the Early Neolithic 'KSC' (KörösStarčevo-Criş) period. Szarvas 23 is a multiperiod site, with findings from the Early Neolithic Körös culture (6000-5450 cal BC) and, among others, a cemetery of the Sarmatian period ( 1 st -4 th centuries $\mathrm{AD}$ ) as well as graves of the Hungarian Conquest period (10th century $\mathrm{AD}$ ). The skeletons involved in the Guba et al ${ }^{1}$ article come from two graves, Nos. 20 and 22, both indicated as Early Neolithic. In fact grave 22 is Sarmatian with special Roman pottery, (terra sigillata) placed near the skeleton as a grave good..$^{2-4}$ According to the excavator, I. Juhász, grave 20 is in fact a Hungarian Conquest period (Magyar) skeleton buried with a horse, dated to the 10th century AD.

(II) Csongrád-Bokros, with one grave claimed to belong to the Neolithic 'ALP' (Alföld Linear Pottery end of 6th Mill. BC) culture. However, this site is also a Sarmatian (1st-4th centuries AD) settlement. According to the documentation of the excavation (7-8 August, 1979, pp 35-37) the following is reported: 'Inside Pit No. 20, at a depth of $50 \mathrm{~cm}$... parts of a human skeleton were found. The remains consisted of a left arm and left leg, as well as some ribs... the fill of the pit contained both Neolithic and Sarmatian pottery fragments, Sarmatian sherds were found even below the skeleton'. An oral communication was added by the archaeologist LA Horváth, who studied the findings of the site: 'the fragmented skeleton was considered Sarmatian already during the excavation'.

(III) Szakmár-Kisülés, with one grave claimed to belong to the Neolithic 'KSC' (Körös-Starčevo-Criş) period. This site is a settlement of the Körös culture, which was disturbed by diggings of a series of later periods, including a Sarmatian cemetery. In the excavation report it was stated that graves 2 and 3 belonged to the Early Neolithic Körös culture. $^{5}$ About grave 8 the following description can be found in the 1976 excavation documentation (pp. 2-3): 'Each of the graves 5-8 were disturbed, none of them belonged to the Körös culture. Grave No. 8: a skeleton disturbed and robbed, the bones are not in anatomic order. Grave goods: a piece of bronze, a spiral of a bronze fibula, several glass and chalk pearls. The grave can be dated to the Sarmatian period'.

(IV) The individual from Kisköre-Gát can probably be assigned, and one specimen from Szegvár can definitely be assigned, to the Late Neolithic Tisza culture (5000-4500 BC) instead of the indicated earlier periods of the Neolithic., ${ }^{6,7}$ The Late Neolithic dating of the Kisköre-Gát grave is estimated by the excavator, on the basis of its position. ${ }^{8}$

Consequently, six out of the eleven graves considered to be Neolithic were clearly misdated. In addition, six individuals of this dataset were attributed to an East Asian hg (three N9a, one D1/G1a1, one M/R24 and one C5). Obviously, the presence of East Asian hg in European sites is unusal and presents an important finding for the reconstruction and timing of past population movements. However, exactly the three individuals with the N9a hg (Szarvas 23 grave 20, Szakmár-Kisülés 8, and Csongrád-Bokros, grave inside Pit 20) can be considered to the Sarmatian and, in one case, early Hungarian (Magyar) period. Thus, all N9a specimens from the Early Neolithic dataset (the first half of the 6th millennium BC) 
Table 1. Summary of published and revised archaeological and genetic information

\begin{tabular}{|c|c|c|c|c|c|c|}
\hline Specimen & Dating & Revised dating & Haplotype & hg & Revised hga & (East) Asian hg \\
\hline Szarvas $23 / 22$ & KSC & Sarmatian & 16235G 16261T 16291T 16293G 16304C & Novel & $\mathrm{H}$ ? & \\
\hline Szarvas $23 / 20$ & KSC & Hung. Conq. p. & 16223T 16257A 16261T & N9a & N9a & + \\
\hline Szakmár-Kisülés8 & $\mathrm{KSC}$ & Sarmatian & 16223T 16257A 16261T & N9a & N9a & + \\
\hline Csongrád-Bokros 20 & ALP & Sarmatian & 16223T 16257A 16261T & N9a & N9a & + \\
\hline Ecsegfalva $23 \mathrm{~A}$ & ALP & ALP & 16147a 16172C 16189C 16223T 16248T 16274A 16355T & N1a & N1a1 & \\
\hline Kisköre-Gát 15 & ALP & Tisza? & 16223T 16325C 16362C & D1/G1a1 & $\mathrm{D} 1 / \mathrm{G} 1 \mathrm{a} 1$ & + \\
\hline Vörs 52 & KSC & Starčevo & 16223T 16288C 16298C 16327T & C5 & C5 & + \\
\hline Mezőkövesd 25 & ALP & ALP & $16324 \mathrm{C}$ & M/R24 & $H$ ? & + \\
\hline Aszód & Late Neolithic & Tisza & - & $\mathrm{H}$ & $\mathrm{H} / \mathrm{HV} / \mathrm{U} / \mathrm{R}$ & \\
\hline Folyas & ALP & ALP & - & H & $\mathrm{H} / \mathrm{HV} / \mathrm{U} / \mathrm{R}$ & \\
\hline Szegvár & $\mathrm{KSC}$ & Tisza & - & H & $\mathrm{H} / \mathrm{HV} / \mathrm{U} / \mathrm{R}$ & \\
\hline
\end{tabular}

Abbreviations: ALP, Alföld Linear Pottery culture; Hung. Conq. p, Hungarian Conquest period; hg, haplogroup; KSC, Körös-Criş-Starčevo culture.

Misdating and insufficient haplogroup classification of the samples are shaded in grey. The last column summarise the influence of the revison on (East) Asian haplogroups in the Neolithic dataset. awww.phylotree.com, built 14 (5 Apr 2012).

originated from a much younger period than reported: the 1st millennium AD. Additionally the D1/G1al individual from KisköreGát was also misdated.

Furthermore, we have detected inaccuracies concerning the hy classification of the mitochondrial sequences. In three graves, the HVS-I sequences are insufficient for a definite classification into the known mitochondrial phylogeny (Szarvas 23 grave 22, Kisköre-Gát 15 and Mezökövesd 25). In these cases, the authors listed all possible hg or indicated the sequence as 'novel'. However, in some cases these assignments are incorrect. The haplotype of Szarvas 23 grave 22 should not be determined as 'novel' because this sequence most likely belongs to the European hg H. ${ }^{9}$ Similarly, the $16324 \mathrm{C}$ haplotype of the Mezökövesd individual was previously described from several studies as hg $\mathrm{H}^{10}$ As a result, these unspecific haplogroup classifications introduced a higher frequency of East Asian hg. In all these cases, additional analysis of diagnostic coding region SNPs are required in order to unambiguously assign the correct hg. This also includes the three CRS individuals reported as hg $\mathrm{H}$ (Aszód, Folyás 111 and Szegvár 25), which also could belong to the hg HV, R or U.

Owing to the fact that six skeletons of the supposed Neolithic dataset had been misdated, and some haplotypes had been insufficiently classified, we cannot support the conclusion of a high frequency of East Asian hg (especially N9a) in Neolithic cultures of the Carpathian Basin. In fact, only two Neolithic individuals remain with an East Asian hg (Vörs, hg C5 and Kisköre-Gát 15, hg D1/G1a1) (Table 1) while only Vörs can be ascribed to the Early Neolithic (Starčevo culture). In the light of all these facts both results now seem questionable.
In contrast to the misdating itself, we do not question the integrity of the finding of hg N9a in a Sarmatian and Magyar context. Sarmatians migrated in the early first Millennium AD, Magyars in the late first Millenium, from the steppe region of present Russia and Ukraine to Eastern Hungary. The highest frequency of the published N9a haplotype (16223T 16257a 16261T) can be found in modern populations of East Asia (Vietnam $(0,78 \%)$, China $(0,23 \%)$, Thailand $(0,14 \%))$ as well as Central Asia (Kyrgyzstan $(0,28 \%)$, Kazakhstan (0,22\%), Uzbekistan (0,21\%) and the Buryat Republic (0,13\%)) (references available upon request). Thus, the observation of high N9a frequencies in a Sarmatian and Magyar population may well support an (East?) Asian affinity.

The data presented in this study were claimed to be the first archaeogenetic dataset of Neolithic cultures of the Carpathian Basin. However, the fact that previously published data were included is not obvious in the article, which is misleading. Some of these samples have already been published (Ecsegfalva $23 \mathrm{~A}^{11}$ and Szarvas 23 grave $20^{12}$ ). The latter article by Burger et al mentions the very same grave (Szarvas 23 grave 20), presented in the paper by Guba et al as belonging to the Early Neolithic Körös culture, while they are, as shown above, 6000 years later. In the Burger et al study this misdating occurs repeatedly, with yet another, Sarmatian grave (Szarvas 23, grave 4). All these cases of misdating could have been avoided by applying $14 \mathrm{C}$ dating. In the article by Guba et al. there is a general reference to $14 \mathrm{C}$ dates, ${ }^{13}$ but this study is focused on another period. Unfortunately, all efforts to produce authentic ancient DNA data are worthless if the archaeological background to a genetic project is missing or insufficiently explored.
The problems discussed represent a caveat for all contributors to the archaeogenetic literature. Mistakes can occur when authors of archaeogenetic studies neglect both the archaeological context of the skeletons studied and the archaeological literature about the sites involved. While one cannot expect molecular biologists to scrutinise minor excavation reports, let alone hunt for unpublished documentation, it is all the more important to integrate archaeologists into the research process. This would not only solve the problem of dating a skeleton 6000 years earlier than its real age, but would also share responsibility for the results and establish real interdisciplinarity between archaeology and the natural sciences.

\section{ACKNOWLEDGEMENTS}

The authors wish to thank I Juhász and LA Horváth for their kind oral information about the Szarvas grave 20 and Csongrád grave in Pit No. 20 datings.

\section{Eszter Bánffy ${ }^{1}$, Guido Brandt ${ }^{2}$ and} Kurt W Alt ${ }^{2}$

${ }^{1}$ Institute of Archaeology,

Research Centre for the Humanities, Hungarian Academy of Sciences, Budapest, Hungary and ${ }^{2}$ Institute of Anthropology, Johannes Gutenberg University Mainz, Mainz, Germany E-mail: banffy.eszter@btk.mta.hu

1 Guba, Z., Hadadi, É., Major, Á., Furka, T., Juhász, E. Koós, J. et al. HVS-I polymorphism screening of ancient human mitochondrial DNA provides evidence for N9a discontinuity and East Asian haplogroups in the Neolithic Hungary. J. Hum. Genet 56, 784-796 (2011)

2 Jankovich, B. D., Makkay, J. \& Szőke, B. M (eds) Magyarország régészeti topográfiája 8. A szarvasi járás (The Archaeological Topography of Hungary 8. the Szarvas district) (Akadémiai Kiadó, Budapest, 1989). 
3 Juhász, I. Mázas római edény Szarvasról. A Békés megyei múzeumok közleményei 23, 89-97 (2002).

4 Makkay, J. The excavations of the early neolithic sites of the Körös culture in the Körös valley, Hungary: the final report. Vol. I: The excavations: stratigraphy, structures and graves (Societa per la preistoria e protoistoria della regione Friuli-Venezia Giulia, Trieste, 2007).

5 Bognár-Kutzián, I. Ausgrabungen in Szakmár-Kisülés im Jahre 1975. Mitteilungen des Archäologischen Instituts der Ungarischen Akademie der Wissenschaften 7, 13-17 (1977).

6 Korek, J Die Theiss-Kultur in der mittleren und nördlichen Theissgegend (Inventaria Praehistorica Hungariae III, Budapest, 1989).
7 Korek, J Szegvarr-Tüzköves, in The Late Neolithic of the Tisza region (ed L, Tálas) 47-60 (Kossuth Press, Budapest-Szolnok, 1987).

8 Siklósi, Zs. A társadalmi egyenlötlenség nyomai a késô neolitikumban a Kárpát-medence keleti felén (Traces of social inequality in the Late Neolithic, in the eastern half of the Carpathian Basin). Unpublished PhD dissertation, ELTE Institute of Archaeological Sciences, Budapest, (2010).

9 Sykes, B. Blood of the Isles (Bantam Press, London, 2006).

10 Behar, D. M., Rosset, S., Blue-Smith, J., Balanovsky, O., Tzur, S., Comas, D. et al. The Genographic Project public participation mitochondrial DNA database.
PLoS Genet. 3, e104 (2007) Erratum in: PLoS Genet. September 14;3(9):1785 (2007).

11 Haak, W., Forster, P., Bramanti, B., Matsumura, S., Brandt, G., Tänzer, M. et al. Ancient DNA from the first European farmers in 7500-year-old Neolithic sites. Science 310, 1016-1018 (2005).

12 Burger, J., Kirchner, M., Bramanti, B., Haak, W. \& Thomas, M. G. Absence of the lactase-persistenceassociated allele in early Neolithic Europeans. Proc. Natl Acad. Sci. USA 104, 3736-3741 (2007).

13 Hertelendi, E., Svingor, É., Raczky, P., Horváth, F., Futó, I. \& Bartosiewicz, L Duration of tell settlements at four prehistoric sites in Hungary. Radiocarbon 40, 659-667 (1998). 